\title{
PECULIARITIES OF PENSION PROVISION OF SERVICEMEN IN UKRAINE
}

\author{
Anna Sayko ${ }^{1}$, Tatiana Shapovalova ${ }^{2}$ \\ Lviv Polytechnic National University, Lviv, Ukraine \\ ${ }^{1}$ Student of bachelor «Social welfare», of Departament of Sociologi and Social work, \\ ${ }^{2}$ Candidate of Economic Sciences, Associate Professor, Department of Sociology and Social Work,
}

Background: There is currently an urgent need for the State to provide decent social security for military personnel, who must in some way compensate for the extra workload associated with the particular military and often life and health risks. Today, this topic is very relevant, as the war in the East of Ukraine has been going on for the sixth year.

Reducing the social level of military personnel, failure to meet generally accepted standards, and the absence of a logical and well-defined policy of social norms, which leads to low levels of combat readiness of the armed forces, lack of a spirit of perseverance in their professional training, and a decrease in the moral qualities of the social security are all low levels of protection. , including retirement benefits, military personnel.

Purpose: To analyze the state of pension provision of military personnel in Ukraine.

Methods: This study was based on general scientific methods, including content analysis and comparison of laws and scientific literature to uncover the basic concepts of research.

Results: Retirement is an important component of the social status of the military and I believe it should ensure a prosperous and decent standard of living. Now servicemen risk their lives and health, protecting their country, so in the future the state should provide them with a decent pension

Conclusion: Having analyzed the state of retirement extended service staff and considering the situation that remains in the retirement service, which is still losing its service, I want to say that there is a real situation in the composition; . In my opinion, left unprotected, it was all raised while working, and after that another contract was reached and another highly paid job was found.

I would also like to add that for persons dismissed from military service, there should be not only decent retirement but also psychological support for former servicemen and their families. This is no less important factor in today's environment.

Speaking about the technology of providing pensions, it can be said that the processes of reforming the defense sector require the improvement and adoption of legislative and other legal acts that correspond to the real state of social relations and economic opportunities of the state, create real and effective legal mechanisms for the implementation of pension provision for military personnel.

Keywords: retirement pension for military personnel, social security, persons dismissed from military service.

Від наповненості державного бюджету i його належного функціонування залежить фінансування соціального захисту населення, зокрема пенсійного забезпечення військовослужбовців та членів їх сімей. Від систематичної і планової політики, залежить продуктивність забезпечення соціального напрямку, головна мета якої повинна бути направлена на підвищення соціального статусу військовослужбовців, адже вони мають значно більші загрози поранення або загибелі порівняно з іншими громадянами під час проведення бойових дій, участі в військових конфліктах та виконанні завдань по захисту незалежності держави. Визначення дієвої системи фінансування сфери соціального забезпечення військових значно прискорює темп становлення стандартів соціального захисту військових Збройних Сил України та відповідного виконання ними завдань, які постали перед українською державою на цьому етапі розвитку країни 3 урахуванням вимог, що ставляться Європейським Союзом та країнами-членами НАТО.(Карпенко, 2010)

Складовою соціального забезпечення військовослужбовців та членів їх сімей є пенсійне забезпечення, яке повинно гарантувати їм гідний рівень життя у разі досягнення ними вислуги років, отримання інвалідності , або отримання виплат членам сім'ї у випадках, визначених Законом. На сьогодні актуальним залишається питання, пов'язаним із проведенням пенсійної 
реформи пенсійне забезпечення військовослужбовців. Сьогодні стає досить гострою соціальною проблемою, те що реформування системи пенсійного забезпечення не торкнулося пенсій колишніх військовослужбовців. (Кириленко 2016)

Одним з найактуальніших питань, пов'язаних з реалізацією пенсійної реформи та 3 метою уникнення "зрівнялівки" у розмірах пенсій різних категорій населення, слід забезпечити особливі умови нарахування пенсійного забезпечення військових, які впродовж довгих років виконували обов'язки, пов'язані із захистом Батьківщини та не мали іншого джерела доходів, окрім грошового забезпечення. При цьому не обов'язково виносити окремий закон щодо перерахунку розміру пенсій військовим, уряд повинен виконати діючий, тобто врахувати розміри грошового утримання, які регламентуються Постановою КМУ №704 "Про грошове забезпечення військовослужбовців, осіб рядового і начальницького складу та деяких інших осіб", яка набирає чинності з 01.01.2018 року.( «Закон Про пенсійне забезпечення осіб, звільнених з військової служби, та деяких інших осіб.»)

Наводячи приклад закордонного досвіду, а саме США то слід зазначити, що там пенсійне забезпечення громадян, звільнених 3 військової служби, - це важлива частина державної системи соціального захисту військовослужбовців і один 3 основних елементів їх матеріального стимулювання. Американська система пенсійного забезпечення військовослужбовців $є$ комплексною і включає власне військову пенсію, пенсію за програмою федерального соціального страхування і особисті відрахування військовослужбовців на персоніфіковані пенсійні рахунки. За оцінками експертів міністерства праці США військовослужбовці на даний час являють собою найбільш соціально захищену професійну групу населення в країні, , завдяки такій системі пенсійного забезпечення. Також я вважаю, що слід зазначити, що у США система пенсійного забезпечення була введена в 1935 році законом, який (з численними змінами) діє і на сьогодні. На мою думку нашій країні слід взяти до уваги таку систему пенсійного забезпечення.

\section{References}

Karpenko, M. (2010). Legal work in the Armed Forces of Ukraine. Kiev: Military Institute.

Kirilenko, V. (2016). Social protection of military personnel as a means of preventing conflict between the army and society. Conflicts in society: diagnosis and prevention. Chernivtsi: Yuriy Fedkovych Chernivtsi National University.

Ukraine. "Law on Retirement Benefits of Discharged Persons and Some Other Persons." No. 2262XII. (1992). URL: https://zakon.rada.gov.ua/laws/show/2262-12.

\section{Список використаних джерел}

Карпенко, М. (2010). Правова робота в Збройних Силах Украӥни Навчальний посібник. Київ: Військовий інститут.

Кириленко, В. (2016). Соціальний захист військовослужбовців як засіб запобігання конфлікту між армією і суспільством. Конфлікти в суспільстві: діагностика і профілактика. Чернівці: Чернівецький національний університет імені Юрія Федьковича.

Україна. «Закон Про пенсійне забезпечення осіб, звільнених з військової служби, та деяких інших осіб.»№2262-XII.(1992). URL: https://zakon.rada.gov.ua/laws/show/2262-12 .

\section{Contact information:}

Сайко Анна

annasayko98@gmail.com 